\title{
Nutrient uptake in tropical turfgrasses growing in winter in southern Queensland
}

\author{
C. M. Menzel ${ }^{\mathrm{A}, \mathrm{C}}$ and P. Broomhall $\mathrm{B}$ \\ ${ }^{A}$ Department of Primary Industries and Fisheries, PO Box 5083, SCMC, Nambour, Qld 4560, Australia. \\ ${ }^{B}$ Hortech Services Pty Ltd, PO Box 126, Amiens, Qld 4352, Australia. \\ ${ }^{\mathrm{C}}$ Corresponding author. Email: chris.menzel@dpi.qld.gov.au
}

\begin{abstract}
The effects of fertilisers on 8 tropical turfgrasses growing in 100-L bags of sand were studied over winter in Murrumba Downs, just north of Brisbane in southern Queensland (latitude $27.4^{\circ} \mathrm{S}$, longitude $153.1^{\circ} \mathrm{E}$ ). The species used were: Axonopus compressus (broad-leaf carpetgrass), Cynodon dactylon (bermudagrass 'Winter Green') and $C$. dactylon $\times$ C. transvaalensis hybrid ('Tifgreen'), Digitaria didactyla (Queensland blue couch), Paspalum notatum (bahiagrass '38824'), Stenotaphrum secundatum (buffalograss 'Palmetto'), Eremochloa ophiuroides (centipedegrass 'Centec') and Zoysia japonica (zoysiagrass 'ZT-11'). Control plots were fertilised with complete fertilisers every month from May to September (72 kg N/ha, $31 \mathrm{~kg} \mathrm{P} / \mathrm{ha}, 84 \mathrm{~kg} \mathrm{~K} / \mathrm{ha}, 48 \mathrm{~kg} \mathrm{~S} / \mathrm{ha}, 30 \mathrm{~kg} \mathrm{Ca} / \mathrm{ha}$ and $7.2 \mathrm{~kg} \mathrm{Mg} / \mathrm{ha}$ ), and unfertilised plots received no fertiliser. Carpetgrass and standard bermudagrass were the most sensitive species to nutrient supply, with lower shoot dry weights in the unfertilised plots (shoots mowed to thatch level) compared with the fertilised plots in June. There were lower shoot dry weights in the unfertilised plots in July for all species, except for buffalograss, centipedegrass and zoysiagrass, and lower shoot dry weights in the unfertilised plots in August for all species, except for centipedegrass. At the end of the experiment in September, unfertilised plots were $11 \%$ of the shoot dry weights of fertilised plots, with all species affected. Mean shoot nitrogen concentrations fell from 3.2 to $1.7 \%$ in the unfertilised plots from May to August, below the sufficiency range for turfgrasses $(2.8-3.5 \%)$. There were also declines in $\mathrm{P}(0.45-0.36 \%), \mathrm{K}(2.4-1.5 \%), \mathrm{S}(0.35-0.25 \%), \mathrm{Mg}(0.24-0.18 \%)$ and $\mathrm{B}(9-6 \mathrm{mg} / \mathrm{kg})$, which were all in the sufficiency range. The shoots in the control plots took up the following levels ( $\mathrm{kg} / \mathrm{ha}$.month) of nutrients: $\mathrm{N}, 10.0-27.0 ; \mathrm{P}, 1.6-4.0 ; \mathrm{K}, 8.2-19.8 ; \mathrm{S}, 1.0-4.2 ; \mathrm{Ca}, 1.1-3.3$; and $\mathrm{Mg}, 0.8-2.2$, compared with applications (kg/ha.month) of: $\mathrm{N}, 72 ; \mathrm{P}, 31 ; \mathrm{K}, 84 ; \mathrm{S}, 48 ; \mathrm{Ca}, 30$; and $\mathrm{Mg}, 7.2$, indicating a recovery of $14-38 \%$ for N, 5-13\% for P, $10-24 \%$ for $\mathrm{K}, 2-9 \%$ for $\mathrm{S}, 4-11 \%$ for $\mathrm{Ca}$ and $11-30 \%$ for $\mathrm{Mg}$. These results suggest that buffalograss, centipedegrass and zoysiagrass are less sensitive to low nutrient supply than carpetgrass, bermudagrass, blue couch and bahiagrass. Data on nutrient uptake showed that the less sensitive species required only half or less of the nitrogen required to maintain the growth of the other grasses, indicating potential savings for turf managers in fertiliser costs and the environment in terms of nutrients entering waterways.
\end{abstract}

Additional keywords: shoot nutrient concentrations, warm season grasses.

\section{Introduction}

The discharge of nutrients such as nitrogen $(\mathrm{N})$ and phosphorus $(\mathrm{P})$ from urban areas along the coast is one of the major issues facing catchments in Queensland and New South Wales, with blue-green algal blooms common in tropical estuaries and bays (Costanzo et al. 2003; Harris 2001; Taylor et al. 2004). The development of appropriate guidelines to reduce the movement of these nutrients from fertilised parks, gardens, sports fields, etc. into waterways and other marine environments (Shuman 2004; Wong et al. 1998) is a necessity.

There have been several studies on the effects of fertilisers on the growth of tropical turfgrasses in North America (Turner and Hummel 1992), but few investigations in Australia. High N applications increased leaf colour, shoot density and clipping weight, but reduced root growth (Carrow et al. 2001). There were also problems with thatch accumulation under high $\mathrm{N}$ regimes in some experiments. Thatch is the tightly intermingled layer of dead and living stems and roots that develops between the green vegetation of the turf and the soil surface. Generally over-fertilisation with $\mathrm{N}$ produces succulent growth that is less wear tolerant (Lunt 1954), although there may be exceptions. The response of turfgrasses to $\mathrm{P}$ was generally not as dramatic as that shown with $\mathrm{N}$, and often inconsistent (Carrow et al. 2001), although colour and visual ratings were often higher with P. Potassium (K) has been shown to increase the growth of bermudagrass (Cynodon dactylon and C. dactylon $\times C$. transvaalensis), centipedegrass (Eremochloa ophiuroides) and zoysiagrass (Zoysia japonica) (Keisling 1980; Pritchett and Horn 1966). 
Potassium has also been reported to improve colour, general quality and sometimes wear resistance in these species.

The response of grasses to fertilisers has generally been related to the amount of the applied nutrients, with the relationship between plant growth and shoot nutrient concentrations receiving less attention. Jones (1980) suggested sufficiency ranges for grasses in the USA, although they were relatively broad. For instance, the optimum concentration for $\mathrm{N}$ was from 2.8 to $3.5 \%$, from 0.30 to $0.55 \%$ for $\mathrm{P}$, and from 1.0 to $2.5 \%$ for $\mathrm{K}$. McCrimmon (1998) studied the mineral composition of 15 bermudgrasses in Louisiana with low and high $\mathrm{N}$ and $\mathrm{K}$ applications. Nutrient concentrations varied with the cultivar, although the differences were generally small, with high nutrient applications not necessarily increasing shoot $\mathrm{N}$ or K. Under high $\mathrm{N}$ and $\mathrm{K}$ supply, shoot nutrient concentrations were as follows: $\mathrm{N}, 3.9-4.6 \%$; $\mathrm{P}, 0.32-0.41 \%$; $\mathrm{K}, 1.9-2.7 \%$; $\mathrm{S}$, $0.32-0.49 \%$; $\mathrm{Ca}, 0.42-0.62 \%$; and $\mathrm{Mg}, 0.14-0.21 \%$.

This paper reports on the effects of nutrition on 8 tropical grasses growing in winter in Pine Rivers Shire just north of Brisbane. Fertiliser was withdrawn from half the plots, and the impacts on growth and shoot nutrient concentrations assessed. The response of the grasses was assessed to determine their relative sensitivity to nutrients being withdrawn. There are potential savings for park managers (less fertilisers) and the environment (less discharge of nutrients into waterways) by more closely matching fertiliser applications to plant nutrient uptake in different species. Beard (1973) recommended a range of $\mathrm{N}$ applications for tropical grasses in the USA, suggesting 5-20 kg N/ha.month for centipedegrass, bahiagrass and carpetgrass; $25-50 \mathrm{~kg} \mathrm{~N} /$ ha.month for buffalograss and zoysiagrass; and $40-90 \mathrm{~kg} \mathrm{~N} / \mathrm{ha}$.month for bermudagrass. Beard did not indicate whether the bermudagrasses required more fertiliser than the other species because they grew more rapidly or because they had higher shoot nutrient contents.

\section{Materials and methods}

\section{Treatments}

Experiments were conducted on 8 tropical grasses, including Axonopus compressus (broad-leaf carpetgrass), Cynodon dactylon (bermudagrass 'Winter Green') and $C$. dactylon $\times C$. transvaalensis hybrid ('Tifgreen'), Digitaria didactyla (Queensland blue couch), Paspalum notatum (bahiagrass ' 38824 '), Stenotaphrum secundatum (buffalograss 'Palmetto'), Eremochloa ophiuroides (centipedegrass 'Centec') and Zoysia japonica (zoysiagrass 'ZT-11') (see Appendix 1) growing in 100-L bags of sand in the full sun at Murrumba Downs in Pine River Shire, north of Brisbane (latitude $27.4^{\circ} \mathrm{S}$, longitude $153.1^{\circ} \mathrm{E}$ ). The bags were filled with sand to about $5 \mathrm{~cm}$ from the top to allow for the growth of the grasses, and had $0.25 \mathrm{~m}^{2}$ of turf once the grasses had established.

The grasses were planted as sprigs in October 1999, fertilised (as the same rates as the control plots given below) and mown every month to thatch level $(10 \mathrm{~mm})$ all year round, with the experiment commencing in April 2001 when the plants were mowed to thatch level and fertiliser withdrawn from half the plots. There was no dethatching or aerating of the grass plots. An individual sprinkler, with variable diameter control was installed in each bag and set to cover $100 \%$ of the surface area, with the sprinkler delivering $90 \mathrm{~L} / \mathrm{h}$. Total available plant water in the bags was $50 \mathrm{~mm}$, with the grasses receiving an irrigation of $28 \mathrm{~mm} /$ week.

Control plots were fertilised monthly from April to October, while unfertilised plots received no fertiliser from May. The experiment was laid out in factorial design ( 8 cultivars $\times 2$ fertiliser treatments), with 4 or 5 bags per treatment across 2 randomised blocks. The cultivars and fertiliser treatments were randomised in each block. Each fertilised plot (plant bag) received $1.8 \mathrm{~g} \mathrm{~N}, 0.8 \mathrm{~g} \mathrm{P}, 2.1 \mathrm{~g} \mathrm{~K}, 1.2 \mathrm{~g} \mathrm{~S}, 0.75 \mathrm{~g} \mathrm{Ca}$ and $0.18 \mathrm{~g} \mathrm{Mg}$ every month in a granular form, plus trace nutrients, equivalent to $72 \mathrm{~kg} \mathrm{~N} / \mathrm{ha}, 31 \mathrm{~kg} \mathrm{P} / \mathrm{ha}, 84 \mathrm{~kg} \mathrm{~K} / \mathrm{ha}, 48 \mathrm{~kg} \mathrm{~S} / \mathrm{ha}$, $30 \mathrm{~kg} \mathrm{Ca} / \mathrm{ha}$ and $7.2 \mathrm{~kg} \mathrm{Mg} / \mathrm{ha}$. The fertiliser was spread by hand to the top of each bag and watered in. The fertiliser applications were higher than those cited by Carrow et al. (2001) for grasses in the USA (8-50 kg N/ha; 3-12 kg P/ha and 4-33 kg K/ha), although Beard (1973) recommended rates of $\mathrm{N}$ for bermudagrass similar to those used here (40-90 kg N/ha). Beard was working in an era of high fertiliser use before light, more frequent applications became the norm for many sites, especially on recreational sites. Earlier research also did not take into account nutrient applications based on seasonal demand.

\section{Data collection}

Soil chemistry at the start of the experiment was as follows: $\mathrm{pH}\left(\mathrm{H}_{2} \mathrm{O}\right)$, 6.9; organic carbon, $0.2 \%$; $\mathrm{NO}_{3}-\mathrm{N}, 0.5 \mathrm{mg} / \mathrm{kg}$; P (Colwell), $10 \mathrm{mg} / \mathrm{kg}$; exchangeable $\mathrm{K}, 0.02 \mathrm{cmol}(+) / \mathrm{kg}$; exchangeable Ca, $0.34 \mathrm{cmol}(+) / \mathrm{kg}$; exchangeable $\mathrm{Mg}, 0.08 \mathrm{cmol}(+) / \mathrm{kg} ; \mathrm{Cl}, 10 \mathrm{mg} / \mathrm{kg}$; electrical conductivity (EC), $0.01 \mathrm{dS} / \mathrm{m} ; \mathrm{Cu}, 0.1 \mathrm{mg} / \mathrm{kg} ; \mathrm{Zn}, 0.6 \mathrm{mg} / \mathrm{kg} ; \mathrm{Mn}$, $1 \mathrm{mg} / \mathrm{kg}$; Fe, $10 \mathrm{mg} / \mathrm{kg}$; and B, $0.2 \mathrm{mg} / \mathrm{kg}$. Initial leaf tests indicated that nutrition was optimum for the grasses (Jones 1980). Shoots were harvested for dry matter each month, with the whole shoots harvested down to thatch level (shoot dry weight). Shoot nutrient concentrations were determined for each species from bulked samples harvested from May, June and August. Total N and chloride were determined from $0.4 \mathrm{~g}$ samples dried at $65-80^{\circ} \mathrm{C}$, digested by concentrated $\mathrm{H}_{2} \mathrm{SO}_{4}$ plus selenium catalyst for $3 \mathrm{~h}$, with the digest measured colormetrically in a segmented flow analyser. The other nutrients were determined from a $1.6 \mathrm{~g}$ sample as above, digested in concentrated $\mathrm{HNO}_{3}$, and measured using an ICP-AES (inductively coupled plasma argon emission spectrometer).

\section{Data analysis}

Data on shoot dry weight are the means of 4 control plants and 5 unfertilised plants. Shoot dry weight in the control fertilised plots was analysed by 2 -way analysis of variance $(8$ species $\times 5$ months $\times 2$ blocks, unbalanced design), using Genstat Edition 6 (VSN International Ltd, Hertz, UK) to test the response of the grasses to seasonal changes in temperature during the experiment. Shoot dry weight in the controls and unfertilised plots was analysed by 2 -way ANOVA ( 2 fertiliser treatments $\times 8$ species $\times 2$ blocks, unbalanced design), with each month analysed separately. The data on shoot nutrient concentrations were averaged for the different species $(n=8)$ and months $(n=3)$. Shoot nutrient concentrations and shoot nutrient uptake in the control plots were analysed by 1-way ANOVA ( 8 species $\times 3$ blocks, with each month treated as a block). Shoot nutrient concentrations in the unfertilised plots were analysed by 1 -way ANOVA ( 3 months $\times 8$ blocks, with each species treated as a block). The relationship between nutrient uptake in the fertilised plants and shoot dry weight was analysed by regression analysis. The amounts of nutrients taken up by the shoots were related to the fertiliser applications in the control plots to estimate the recovery of the applied fertiliser.

\section{Weather}

Mean daily maximum temperatures during the experiment ranged from $21.5^{\circ} \mathrm{C}$ in July to $26.1^{\circ} \mathrm{C}$ in April (Table 1). Similarly, mean daily minimum temperatures ranged from $8.7^{\circ} \mathrm{C}$ in August to $16.5^{\circ} \mathrm{C}$ in April. Mean monthly rainfall ranged from 12 to $37 \mathrm{~mm}$, and mean monthly evaporation from 96 to $162 \mathrm{~mm}$. Temperatures and evaporation were 
Table 1. Daily temperatures, and monthly rainfall and evaporation for Murrumba Downs during the experiment

Long-term averages also presented

\begin{tabular}{lcccrrr}
\hline & April & May & June & July & August & September \\
\hline & Daily and monthly averages & for 2001 & & & \\
Mean daily max. temp. $\left({ }^{\circ} \mathrm{C}\right)$ & 26.1 & 23.6 & 22.5 & 21.5 & 22.1 & 24.2 \\
Mean daily min. temp. $\left({ }^{\circ} \mathrm{C}\right)$ & 16.5 & 11.8 & 10.8 & 8.8 & 8.7 & 11.7 \\
Mean monthly rainfall $(\mathrm{mm})$ & 34 & 37 & 17 & 29 & 12 & 13 \\
Mean monthly evaporation $(\mathrm{mm})$ & 144 & 112 & 96 & 102 & 158 & 162 \\
& \multicolumn{7}{c}{ Long-term averages } & & & & \\
Mean daily max. temp. $\left({ }^{\circ} \mathrm{C}\right)$ & 26.3 & 23.5 & 21.2 & 20.6 & 21.7 & 23.8 \\
Mean daily min. temp. $\left({ }^{\circ} \mathrm{C}\right)$ & 16.9 & 13.8 & 10.9 & 9.5 & 10.0 & 12.5 \\
Mean monthly rainfall $(\mathrm{mm})$ & 90 & 99 & 71 & 63 & 43 & 35 \\
Mean monthly evaporation $(\mathrm{mm})$ & 135 & 99 & 90 & 99 & 127 & 165 \\
\hline
\end{tabular}

similar to the long-term averages, whereas rainfall from April to September was much lower $(142 v .401 \mathrm{~mm})$ probably giving less leaching of nutrients than in an 'average' year.

\section{Results}

\section{Shoot dry weight}

Average shoot dry weight in the controls in June was $81 \%$ of the value in May, and 68\% in July, 98\% in August and 127\% in September (Table 2). Centipedegrass was the most cold-sensitive species, with a significantly lower shoot dry weight in July compared with the value in May (ratio of growth in July: growth in May of 25\%). Carpetgrass was also cold sensitive, with a lower shoot dry weight in July compared with the value in May (ratio of 55\%). In contrast, the bermudagrasses, blue couch and bahiagrass were the least sensitive species, with a relative growth (July:May) of $75 \%$ or better.

The unfertilised plots weighed $92 \%$ of the weights of the fertilised plots in May (no significant difference between control and fertilised plots in any of the species), $71 \%$ in June, $33 \%$ in July, $19 \%$ in August and 11\% in September (Table 3). Carpetgrass and the standard bermudagrass were the most sensitive species to nutrient supply, with significantly lower shoot weights in the unfertilised plots compared with the fertilised plots in June (Table 3). There were significantly lower shoot weights in the unfertilised plots in July for all species, except for buffalograss, centipedegrass and zoysiagrass, and significantly lower shoot weights in the unfertilised plots in August for all species, except for centipedegrass. At the end of the experiment in September, all unfertised plots had significantly lower dry weights than the comparative control plot.

\section{Shoot nutrient concentrations}

There were small but significant variations in average nutrient concentrations (except for shoot iron) among the 8 species (Table 4), although it is not known whether these differences are physiologically important. Shoot N decreased by $47 \%$ from May to August in the unfertilised plots (Table 5), and were below the sufficiency range of Jones (1980) at the end of the experiment. There were also declines in shoot P (20\%), K (38\%), S (29\%), Mg (25\%), Cl (41\%), Mn (26\%) and B (33\%).

\section{Nutrient uptake}

Nutrient uptake varied by a factor of 2-4 across the different species (Table 6). Buffalograss, centipedegrass and zoysiagrass had lower uptake of $\mathrm{N}$ than carpetgrass, bahiagrass and the 2 bermudagrasses, associated with lower average shoot dry weight. Buffalograss, centipedegrass and zoysiagrass had lower uptake of calcium than bahiagrass and standard bermudagrass; and buffalograss, centipedegrass, zoysiagrass and hybrid bermudagrass lower uptake of $\mathrm{Mg}$ than bahiagrass.

There was a strong relationship between the uptake of $\mathrm{N}$, $\mathrm{P}, \mathrm{K}, \mathrm{S}$ and $\mathrm{Ca}$, and shoot dry weight (Fig. 1). Plants with high nutrient uptake had greater shoot weights rather than higher nutrient concentrations.

A comparison of the amounts of nutrients in the shoots (Table 6) with the fertiliser applications (see 'Materials and

Table 2. Shoot dry weight (g/plot.month) in the tropical grasses growing in winter and fertilised monthly (control plots) at Murrumba Downs

Fertiliser treatments commenced in May 2001. Shoot dry weights were measured at the start of each month, with values representing the means of 4 plants

\begin{tabular}{lrrrcc}
\hline Species & May & June & July & August & September \\
\hline Carpetgrass & 17.0 & 16.6 & 11.1 & 12.9 & 13.4 \\
Hybrid bermudagrass & 16.0 & 8.4 & 15.5 & 22.4 & 20.8 \\
Bermudagrass & 14.1 & 20.1 & 12.9 & 28.8 & 21.9 \\
Blue couch & 15.3 & 11.6 & 10.9 & 13.3 & 16.4 \\
Bahiagrass & 16.1 & 13.7 & 15.1 & 17.7 & 19.9 \\
Buffalograss & 13.8 & 10.0 & 4.3 & 7.8 & 13.4 \\
Centipedegrass & 16.6 & 8.8 & 3.1 & 6.5 & 30.6 \\
Zoysiagrass & 11.0 & 7.6 & 5.7 & 8.1 & 13.2 \\
1.s.d. $(P=0.05)$ & n.s. & n.s. & 6.9 & 7.5 & 8.8 \\
\hline
\end{tabular}


Table 3. The effects of fertiliser reduction (control, complete fertiliser monthly; UF, no fertiliser) on shoot dry weight (g/plot.month), in tropical grasses grown in winter at Murrumba Downs

Fertiliser treatments commenced in May 2001. Shoot dry weights were measured at the start of each month, with values representing the means of 4 plants for the controls and 5 plants for the unfertilised treatment. The fertiliser treatments had no significant effect $(P>0.05)$ on shoot dry weight in May

\begin{tabular}{|c|c|c|c|c|c|c|c|c|c|}
\hline \multirow[t]{2}{*}{ Species } & \multirow{2}{*}{$\begin{array}{l}\text { May } \\
\text { Mean }\end{array}$} & \multicolumn{2}{|c|}{ June } & \multicolumn{2}{|c|}{ July } & \multicolumn{2}{|c|}{ August } & \multicolumn{2}{|c|}{ September } \\
\hline & & Control & UF & Control & UF & Control & UF & Control & UF \\
\hline Carpetgrass & 16.6 & 16.3 & 9.9 & 11.1 & 4.8 & 13.1 & 3.4 & 13.5 & 2.4 \\
\hline Hybrid bermudagrass & 12.2 & 7.9 & 7.4 & 15.7 & 4.0 & 22.0 & 4.5 & 20.8 & 0.9 \\
\hline Bermudagrass & 11.7 & 19.7 & 5.4 & 13.0 & 2.9 & 28.7 & 2.2 & 22.0 & 1.1 \\
\hline Blue couch & 14.0 & 11.1 & 13.0 & 11.2 & 2.9 & 13.0 & 1.6 & 16.4 & 0.4 \\
\hline Bahiagrass & 18.0 & 13.3 & 8.5 & 15.1 & 4.8 & 17.6 & 3.0 & 20.0 & 4.5 \\
\hline Buffalograss & 12.9 & 9.1 & 5.9 & 4.7 & 1.3 & 7.1 & 1.2 & 13.4 & 0.9 \\
\hline Centipedegrass & 16.5 & 8.1 & 9.2 & 3.4 & 2.4 & 5.8 & 4.1 & 30.6 & 4.3 \\
\hline Zoysiagrass & 10.7 & 7.2 & 6.8 & 5.8 & 3.2 & 8.0 & 2.2 & 13.3 & 1.6 \\
\hline 1.s.d. $(P=0.05)$ & 5.0 & \multicolumn{2}{|c|}{6.4} & \multicolumn{2}{|c|}{4.5} & \multicolumn{2}{|c|}{4.8} & \multicolumn{2}{|c|}{5.2} \\
\hline
\end{tabular}

methods') indicates a recovery of $14-38 \%$ for $\mathrm{N}, 5-13 \%$ for P, $10-24 \%$ for K, $2-9 \%$ for $\mathrm{S}, 4-11 \%$ for $\mathrm{Ca}$ and $11-30 \%$ for $\mathrm{Mg}$. These values do not take into account the uptake of nutrients into new roots $(30 \%$ of the nutrients are in the thatch and roots according to Picchioni and Quiroga-Garza 1999 ) or if the shoot clippings were kept on site $(45 \%$ of the nutrients).

\section{Discussion}

\section{Shoot nutrient concentrations}

Jones (1980) presented optimum nutrient concentrations for grasses: $\mathrm{N}, 2.8-3.5 \% ; \mathrm{P}, 0.30-0.55 \% ; \mathrm{K}, 1.0-2.5 \%$; , $0.20-0.45 \%$; Ca, $0.50-1.25 \% ; \mathrm{Mg}, \quad 0.20-0.60 \%$; Cu, 5-20 mg/kg; Zn, 20-55 mg/kg; Fe, 35-100 mg/kg; Mn, $25-150 \mathrm{mg} / \mathrm{kg}$; and B, $10-60 \mathrm{mg} / \mathrm{kg}$. His values are similar to those presented in Tables 4 and 5, although the range is much wider for most nutrients. Further work is required to determine the optimum nutrient concentrations for different grasses in Australia, with under- or over-fertilisation less likely. McCrimmon (2002) investigated the nutrition of 14 seeded and 1 vegetative bermudagrass in Louisiana, USA given the equivalent of $342 \mathrm{~kg} \mathrm{~N} /$ ha.year. Shoot $\mathrm{N}$ $(2.5-3.5 \%)$ and $\mathrm{P}(0.37-0.46 \%)$ were different in the cultivars in year 2 , but were similar in year $1(4.0 \pm 0.7 \%$ for $\mathrm{N}$ and $0.34 \pm 0.02 \%$ for $\mathrm{P}$ ), and were within the sufficiency ranges in both years. There were also differences in $\mathrm{K}$ $(1.4-2.4 \%), \mathrm{S}(0.37-0.65 \%), \mathrm{Ca}(0.25-0.55 \%)$ and $\mathrm{Mg}$ $(0.10-0.20 \%)$.

The concentrations of $\mathrm{N}$ in the unfertilised plots were below the optimum at the end of the experiment (1.7\%). In contrast, P (0.36\%), K (1.5\%), S (0.25\%) and $\mathrm{Mg}(0.18 \%)$ were in the optimum range. These results suggest that low concentrations of $\mathrm{N}$ reduced the growth of the unfertilised plots. Soil $\mathrm{NO}_{3}-\mathrm{N}(0.5 \mathrm{mg} / \mathrm{kg})$ and organic carbon $(0.2 \%)$ were low at the start of the experiment, indicating that the unfertilised grasses were mainly dependent on the $\mathrm{N}$ reserves in the plants at the start of the experiment.

\section{Uptake of nutrients}

Nutrient uptake varied by a factor of $2-4$ across the group, with the vigorous species having greater nutrient uptake. These data were compared with the amounts of nutrients

Table 4. Shoot nutrient concentrations in the tropical grasses growing in winter and fertilised monthly (control plots) at Murrumba Downs

Fertiliser treatments commenced in May 2001. Shoot dry weights were measured at the start of May, June and August, with values representing the means of 4 plants

\begin{tabular}{|c|c|c|c|c|c|c|c|c|c|c|c|c|c|}
\hline Species & $\begin{array}{c}\mathrm{N} \\
(\%)\end{array}$ & $\begin{array}{c}\mathrm{P} \\
(\%)\end{array}$ & $\begin{array}{c}\mathrm{K} \\
(\%)\end{array}$ & $\begin{array}{c}\mathrm{S} \\
(\%)\end{array}$ & $\begin{array}{c}\mathrm{Ca} \\
(\%)\end{array}$ & $\begin{array}{l}\mathrm{Mg} \\
(\%)\end{array}$ & $\begin{array}{l}\mathrm{Na} \\
(\%)\end{array}$ & $\begin{array}{c}\mathrm{Cl} \\
(\%)\end{array}$ & $\begin{array}{c}\mathrm{Cu} \\
(\mathrm{mg} / \mathrm{kg})\end{array}$ & $\begin{array}{c}\mathrm{Zn} \\
(\mathrm{mg} / \mathrm{kg})\end{array}$ & $\begin{array}{c}\mathrm{Fe} \\
(\mathrm{mg} / \mathrm{kg})\end{array}$ & $\begin{array}{c}\mathrm{Mn} \\
(\mathrm{mg} / \mathrm{kg})\end{array}$ & $\begin{array}{c}\mathrm{B} \\
(\mathrm{mg} / \mathrm{kg})\end{array}$ \\
\hline Carpetgrass & 3.5 & 0.56 & 2.8 & 0.34 & 0.35 & 0.26 & 0.01 & 0.78 & 8 & 30 & 147 & 24 & 11 \\
\hline Hybrid bermudagrass & 3.7 & 0.50 & 2.3 & 0.56 & 0.46 & 0.15 & 0.10 & 0.67 & 7 & 25 & 108 & 47 & 5 \\
\hline Bermudagrass & 3.6 & 0.52 & 2.6 & 0.54 & 0.45 & 0.17 & 0.07 & 0.69 & 7 & 26 & 96 & 53 & 5 \\
\hline Blue couch & 3.5 & 0.65 & 2.9 & 0.30 & 0.49 & 0.23 & 0.35 & 0.86 & 10 & 36 & 128 & 86 & 8 \\
\hline Bahiagrass & 3.5 & 0.50 & 2.3 & 0.51 & 0.50 & 0.36 & 0.02 & 0.43 & 8 & 32 & 136 & 42 & 10 \\
\hline Buffalograss & 3.0 & 0.75 & 2.9 & 0.48 & 0.33 & 0.25 & 0.72 & 1.03 & 11 & 32 & 101 & 49 & 7 \\
\hline Centipedegrass & 2.8 & 0.49 & 2.6 & 0.29 & 0.35 & 0.24 & 0.01 & 0.63 & 10 & 32 & 91 & 42 & 11 \\
\hline Zoysiagrass & 3.0 & 0.45 & 2.3 & 0.44 & 0.43 & 0.21 & 0.05 & 0.45 & 6 & 27 & 267 & 41 & 8 \\
\hline 1.s.d. $(P=0.05)$ & 0.4 & 0.11 & 0.4 & 0.08 & 0.10 & 0.06 & 0.06 & 0.16 & 2 & 5 & n.s. & 12 & 2 \\
\hline
\end{tabular}


Table 5. The effects of fertiliser reduction (control, complete fertiliser monthly;

UF, no fertiliser) on shoot nutrient concentrations in tropical grasses growing at Murrumba Downs in May, June and August

Fertiliser treatments commenced in May 2001. Shoot dry weights were measured at the start of each month, with values representing the means of 4 control plants and 5 unfertilised plants. Values are means \pm s.e. (for control only)

\begin{tabular}{lccccc}
\hline Nutrient & Control & May & $\begin{array}{c}\text { UF } \\
\text { June }\end{array}$ & August & $\begin{array}{c}\text { 1.s.d. }(P=0.05) \\
\text { for UF means }\end{array}$ \\
\hline $\mathrm{N}(\%)$ & $3.3 \pm 0.1$ & 3.2 & 2.4 & 1.7 & 0.5 \\
$\mathrm{P}(\%)$ & $0.55 \pm 0.02$ & 0.45 & 0.51 & 0.36 & 0.05 \\
$\mathrm{~K}(\%)$ & $2.6 \pm 0.1$ & 2.4 & 2.3 & 1.5 & 0.3 \\
$\mathrm{~S}(\%)$ & $0.43 \pm 0.02$ & 0.35 & 0.35 & 0.25 & 0.04 \\
$\mathrm{Ca}(\%)$ & $0.42 \pm 0.02$ & 0.40 & 0.53 & 0.47 & 0.09 \\
$\mathrm{Mg}(\%)$ & $0.23 \pm 0.01$ & 0.24 & 0.24 & 0.18 & 0.02 \\
$\mathrm{Na}(\%)$ & $0.17 \pm 0.05$ & 0.15 & 0.19 & 0.09 & $\mathrm{n} . \mathrm{s}$. \\
$\mathrm{Cl}(\%)$ & $0.69 \pm 0.04$ & 0.74 & 0.64 & 0.40 & 0.11 \\
$\mathrm{Cu}(\mathrm{mg} / \mathrm{kg})$ & $8 \pm 1$ & 7 & 9 & 6 & 2 \\
$\mathrm{Zn}(\mathrm{mg} / \mathrm{kg})$ & $30 \pm 1$ & 27 & 29 & 30 & $\mathrm{n} . \mathrm{s}$. \\
$\mathrm{Fe}(\mathrm{mg} / \mathrm{kg})$ & $134 \pm 18$ & 85 & 94 & 149 & 40 \\
$\mathrm{Mn}(\mathrm{mg} / \mathrm{kg})$ & $48 \pm 4$ & 31 & 33 & 23 & 5 \\
$\mathrm{~B}(\mathrm{mg} / \mathrm{kg})$ & $8 \pm 1$ & 9 & 8 & 6 & 2 \\
\hline
\end{tabular}

supplied in the fertilisers, and show that even allowing for losses of $50 \%$ of the applied nutrients, many of the grasses were over-fertilised. The recovery of applied $\mathrm{N}$ in the shoots ranged from 14 to $38 \%$, and 5 to $13 \%$ for $\mathrm{P}$, under cool temperatures and excessive water applications (discussed below). Bowman et al. (2002) investigated the recovery of $\mathrm{N}$ in 6 warm-season grasses in sand-filled columns in North Carolina, USA. The grasses were given $50 \mathrm{~kg} \mathrm{~N} / \mathrm{ha}$ on several dates, with $63-84 \%$ of the $\mathrm{N}$ recovered, and a strong relationship between recovery and root length density in the different species.

Picchioni and Quiroga-Garza (1999) examined the fate of $\mathrm{N}$, equivalent to 434 or $868 \mathrm{~kg} /$ ha.year applied to 'Tifgreen' hybrid bermudagrass in 2 glasshouse experiments in winter in New Mexico, USA. The recovery of $\mathrm{N}$ in the clippings, verdue (shoot material remaining after mowing), and thatch

Table 6. Mean nutrient uptake (kg/ha.month) in the tropical grasses grown in winter and fertilised monthly (control plots) at Murrumba Downs

Shoot dry weights were measured at the start of each month in May, June and August, with values representing the means of 4 plants

\begin{tabular}{lcccccc}
\hline Species & $\mathrm{N}$ & $\mathrm{P}$ & $\mathrm{K}$ & $\mathrm{S}$ & $\mathrm{Ca}$ & $\mathrm{Mg}$ \\
\hline Carpetgrass & 21.8 & 3.5 & 17.4 & 2.1 & 2.1 & 1.6 \\
Hybrid bermudagrass & 22.0 & 3.1 & 14.5 & 3.4 & 2.6 & 0.9 \\
Bermudagrass & 27.0 & 4.0 & 19.8 & 4.2 & 3.3 & 1.3 \\
Blue couch & 18.5 & 3.4 & 15.5 & 1.6 & 2.6 & 1.2 \\
Bahiagrass & 21.4 & 3.1 & 14.4 & 3.1 & 3.0 & 2.2 \\
Buffalograss & 10.0 & 2.5 & 9.7 & 1.6 & 1.1 & 0.9 \\
Centipedegrass & 10.2 & 1.8 & 9.8 & 1.0 & 1.4 & 0.9 \\
Zoysiagrass & 11.0 & 1.6 & 8.2 & 1.6 & 1.6 & 0.8 \\
1.s.d. $(P=0.05)$ & 10.1 & n.s. & n.s. & n.s. & 1.4 & 0.8 \\
\hline
\end{tabular}

and roots ranged from 38 to $79 \%$, depending on the experiment and source of $\mathrm{N}$ (urea, ammonium nitrate, ammonium sulphate). An average of $45 \%$ of the $\mathrm{N}$ taken up by the grass was in the clippings, $25 \%$ in the verdue and $30 \%$ in the thatch and roots.

Brink et al. (2003) studied the uptake of $\mathrm{N}$ in 7 bermudagrasses in Mississippi, USA on a silty clay loam and a silty loam. There were relatively small differences in nutrient uptake between the cultivars, with $422-467 \mathrm{~kg}$ $\mathrm{N} /$ ha.year taken up in the first soil, and $181-230 \mathrm{~kg}$ $\mathrm{N} /$ ha.year in the second soil, from applications of 200 or $370 \mathrm{~kg} \mathrm{~N} /$ ha.year. Woodard et al. (2003) conducted a similar study in northern Florida, with 500, 600 or $910 \mathrm{~kg} \mathrm{~N} / \mathrm{ha}$.year applied. The grass removed an average of $191 \mathrm{~kg} \mathrm{~N} / \mathrm{ha}$.year over 4 years, with $\mathrm{N}$ applications below $500 \mathrm{~kg} /$ ha.year not expected to degrade ground water. The uptake of $\mathrm{N}$ in our experiment is equivalent to $120-324 \mathrm{~kg} \mathrm{~N} / \mathrm{ha}$ over a 12-month cycle, although the actual rate would be expected to be more than this because of greater plant growth from October to April compared with that from May to September (see Table 2), and the $\mathrm{N}$ stored in the roots and thatch (Picchioni and Quiroga-Garza 1999).

\section{Responses to nitrogen}

The unfertilised plots exhibited shoot weights $92 \%$ of the weights of the fertilised plots in May, $71 \%$ in June, 33\% in July, $19 \%$ in August and $11 \%$ in September (Table 3). Centipede, buffalo and zoysiagrass were more tolerant to low fertility than hybrid bermuda, blue couch and bahiagrass (intermediate tolerance), and carpet and standard bermudagrass (low tolerance). Aldous and Chivers (2002) ranked centipedegrass, buffalograss and zoysiagrass as having a better tolerance to low fertility situations than 


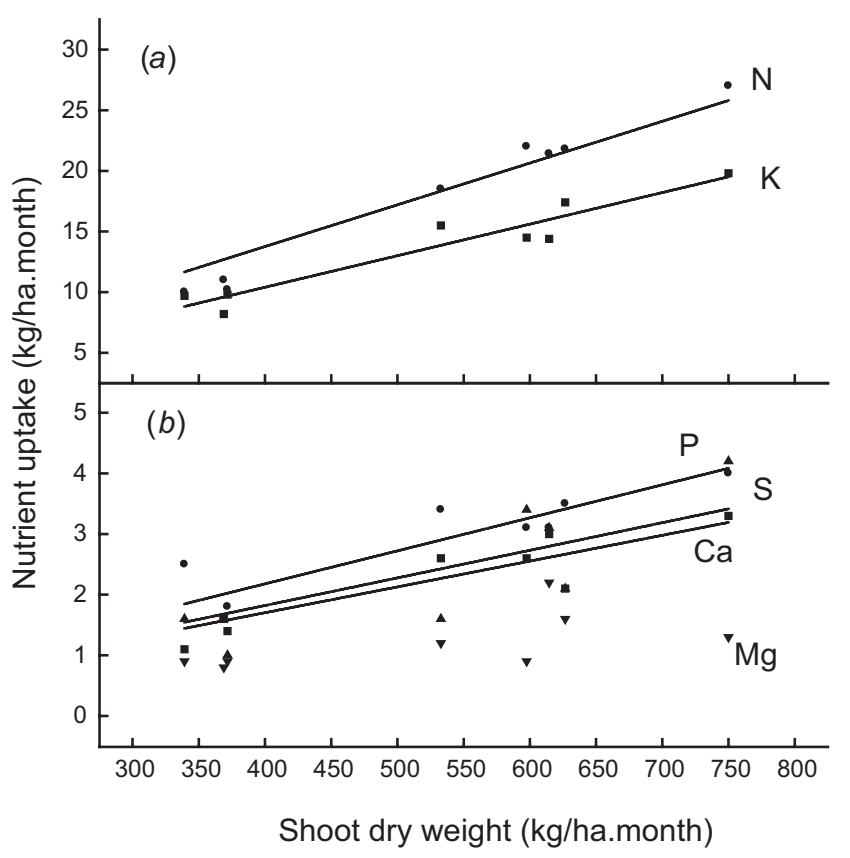

Fig. 1. The relationship between the uptake of $(a)$ nitrogen $(\mathbf{O})$ and potassium (ם), and (b) phosphorus $(\mathbf{O})$, sulfur $(\mathbf{\square})$, calcium $(\boldsymbol{\Delta})$ and magnesium $(\boldsymbol{\nabla})$, and shoot dry weight in tropical grasses at Murrumba Downs. Data are the means of 4 control plants for each of the 8 species. Uptake N $_{\mathrm{N}}=0.0344( \pm 0.0010) \times$ dry weight $\left(R^{2}=0.95\right)$; Uptake $_{\mathrm{p}}=0.0054( \pm 0.0008) \times$ dry weight $\left(R^{2}=0.80\right)$; Uptake $_{\mathrm{K}}=0.0262( \pm 0.0002) \times$ dry weight $\left(R^{2}=0.91\right) ;$ Uptake $_{\mathrm{S}}=0.0043( \pm 0.0002) \times$ dry weight $\left(R^{2}=0.83\right)$; and Uptake $_{\mathrm{Ca}}=0.0046( \pm 0.0004) \times$ dry weight $\left(R^{2}=0.66\right)(P<0.001)$. There was no significant relationship $(P>0.05)$ between the uptake of magnesium and shoot dry weight.

standard and hybrid bermudagrasses and blue couch. The data in Table 6 indicate a relative $\mathrm{N}$ requirement of $70-80 \%$ for carpetgrass, hybrid bermudagrass, blue couch and bahiagrass compared with standard bermudagrass, and $35-40 \%$ for buffalograss, centipedegrass and zoysiagrass. These results in Tables 2, 5 and 6 suggest that it is the relative dry matter production of the tropical grasses which determines their relative fertiliser requirement. Differences in the uptake of $\mathrm{N}$ (and the other nutrients) into the shoots were more related to differences in dry matter of the various species (varied by a factor of 2-4) than to differences in the concentration of $\mathrm{N}$ (ranged from 2.8 to $3.7 \%$ in the 8 species).

In southern USA, centipedegrass and bahiagrass are more competitive than the bermudagrass under low $\mathrm{N}$ regimes (Carrow et al. 2001), although there are strong differences between cultivars within a species. Horticulturists recommend that no $\mathrm{N}$ be applied to warm-season grasses from November to February in cool subtropical New Mexico and Arizona (Picchioni and Quiroga-Garza 1999). However, this strategy does not seem applicable to grasses growing on sands in southern Queensland, with most species affected within 1 or 2 months of fertiliser being withdrawn.
McCaslin et al. (1989) investigated the effects of $\mathrm{N}$ on the performance of 10 bermudagrasses in New Mexico over 3 years, with the plants receiving $0,96,192$ or $288 \mathrm{~kg} \mathrm{~N} / \mathrm{ha}$ in 6 applications from April to September. Leaf colour, stem density and clipping weight increased with N. Goatley et al. (1994) conducted similar research on 'Tifgreen' in Mississippi over 3 years, with 0,49 or $98 \mathrm{~kg} \mathrm{~N} / \mathrm{ha}$ applied in October. Leaf $\mathrm{N}$ concentrations were 3.1, 3.8 and $4.0 \%$ with increasing applications, with leaf colour generally better after $\mathrm{N}$. The fertilised grasses in our experiment had a mean $\mathrm{N}$ concentration of $3.3 \pm 0.1 \%$, whereas the unfertilised grasses had a mean $\mathrm{N}$ concentration of $1.7 \pm 0.2 \%$ in August, suggesting a severe shortage of the nutrient after 6 months. Trenholm et al. (1998) studied the response of 'FloraDwarf' and 'Tifdwarf' bermudagrass in a glasshouse in Florida, with the plants receiving $12,24,49$ or $98 \mathrm{~kg} \mathrm{~N} /$ ha.month under $13.6 \mathrm{~h}$ days and 23, 49, 74 or $98 \mathrm{~kg} \mathrm{~N} / \mathrm{ha}$.month under $12.2 \mathrm{~h}$ days. Shoot growth increased with increasing N. For example, dry matter production in 'FloraDwarf' under long days was $16 \mathrm{~g} / \mathrm{m}^{2}$.week with $12 \mathrm{~kg} \mathrm{~N} /$ ha.month and $48 \mathrm{~g} / \mathrm{m}^{2}$.week with $98 \mathrm{~kg} \mathrm{~N} / \mathrm{ha}$.month. These results demonstrate the strong response to $\mathrm{N}$ in tropical grasses.

Limited data are available on the response of other grasses to N. Burton et al. (1997) investigated the growth of bahiagrass in Georgia over 3 years, and found that 56, 112, 224 or $448 \mathrm{~kg} \mathrm{~N} /$ ha.year gave annual dry matter yields of 6.0 , 8.2, 11.9 and $15.2 \mathrm{t} / \mathrm{ha}$, associated with increasing leaf $\mathrm{N}$. Cisar et al. (1992) examined the performance of 'Floratam' buffalograss on an organic soil in Florida over 2 years. Nitrogen at $300 \mathrm{~kg} /$ ha.year increased visual quality and clipping yield of the sod, and of sod pieces re-established on sand compared with nil $\mathrm{N}$ controls. However, there was no effect on the quality of the sod pieces. The concentration of $\mathrm{N}$ in the leaves was $3.4 \%$ in both treatments. Cisar et al. (1992) suggested that there was sufficient $\mathrm{N}$ in the soil for adequate sod production, with fertiliser applications providing little economic benefit in this environment. In our experiment with the grasses grown in sand, there was insufficient $\mathrm{N}$ in the soil to support the growth of the buffalograss, with an average shoot weight in the unfertilised plots about $50 \%$ of that in the fertilised plots.

\section{Water use}

The grasses in our experiment received an irrigation of $28 \mathrm{~mm} /$ week. Reducing irrigation rates during winter when growth is slow and evapotranspiration low would be expected to minimise the loss of nutrients off-site. Adeli et al. (2003) noted that the recovery of $\mathrm{N}$ in bermudagrass in Mississippi was reduced by more than half when irrigation was extended from September to October. A similar response would be expected in southern Queensland during winter and spring, when plant water use is relatively low. 
Broomhall and Menzel (2002) studied the water use of a range of warm-season grasses at Cleveland in southern Brisbane and found that they used only half the water in winter that they used in summer. Short and Colmer (1999) indicated that the minimum daily irrigation requirement for a range of tropical turfs growing on sand in Perth, Western Australia ranged from 50 to $60 \%$ of evaporation from a Class A pan evaporimeter. Evaporation in this environment ranges from $2 \mathrm{~mm}$ /day in June and July to $10 \mathrm{~mm}$ /day in January, indicating a similar potential water use for warm-season grasses in Murrumba and Perth during winter, but 50\% greater water use in Perth during summer.

\section{Relative cold tolerance of the grasses}

There is little information on the relative growth of tropical turf species under different temperature regimes. In the present experiment, average daily temperatures declined by about $6^{\circ} \mathrm{C}$ from April to July (Table 1), with the average dry weight of the fertilised plots in July only $68 \%$ of that in May. There was also a variation in the response of the different species, with the relative order of increasing cold tolerance: centipedegrass $<$ buffalograss $<$ zoysiagrass $<$ carpetgrass $<$ blue couch $<$ bermudagrass $<$ bahiagrass $<$ hybrid bermudagrass.

Beard (1973) indicated that turfgrasses from warm habitats generally have higher temperature optima than those from cooler environments. The optimum temperature for shoot growth ranged from 27 to $35^{\circ} \mathrm{C}$ for a range of tropical grasses, including bermuda, carpet and zoysia (Brown 1939; Lovvorn 1945; Youngner 1961). In other experiments, the temperature minimum for shoot growth ranged from about $10^{\circ} \mathrm{C}$ in bermudagrass to $16^{\circ} \mathrm{C}$ in zoysiagrass (Brown 1939; Youngner 1959, 1960, 1961). Unruh et al. (1996) modelled the effects of temperatures from $5^{\circ}$ to $30^{\circ} \mathrm{C}$ on leaf elongation in 8 warm-season grasses in glasshouse experiments in Iowa, USA. The base temperature for growth, $\mathrm{T}_{0}$, was $12.3^{\circ} \mathrm{C}$ for centipedegrass, and from $1.2^{\circ}$ to $4.9^{\circ} \mathrm{C}$ for zoysiagrass, bermudagrass and buffalograss. Similarly in our experiment at Murrumba Downs, centipedegrass was more sensitive to lower temperatures in July than most of the other grasses.

\section{Conclusions}

Fertilisers increased the growth of the turfs, with centipedegrass, buffalograss and zoysiagrass less affected by low nutrient supply than carpetgrass, bermudagrass, blue couch and bahiagrass. The less sensitive species required $35-40 \%$ of the $\mathrm{N}$ required by the more sensitive species, a strong indication of the potential savings for park managers and the marine environment. Data on nutrient uptake in the shoots indicated a recovery of $14-38 \%$ of the applied $\mathrm{N}$ in clippings and $5-13 \%$ of the $\mathrm{P}$, suggesting over-fertilisation in the experiment at Murrumba Downs.

\section{Acknowledgments}

We thank Horticulture Australia Limited (HAL), Lend Lease (Rob Ball and Gary Searle) and Lensworth (Alex Plusnin) through their developments in Brisbane, Pine Rivers Shire Council (Michael Gash, Nursery Technician, Bob Bannon, Supervisor and Helen Walker, Assistant Chemist), Calliope Shire Council (Jeff Kidner), Townsville City Council (Ross Pillar), Jimboomba Turf (Lynn Davidson) and Twin View Turf (Max Stephenson). Special appreciation to Roger Smart, Lin O'Brien and Matt Limpus from the Department of Primary Industries and Fisheries, and Neil Power from Brisbane.

\section{References}

Adeli A, Varco JJ, Rowe DE (2003) Swine effluent irrigation rate and timing effects on bermudagrass growth, nitrogen and phosphorus utilization, and residual soil nitrogen. Journal of Environmental Quality 32, 681-686.

Aldous DE, Chivers IH (2002) 'Sports turf and amenity grasses. A manual for use and identification.' (Landlinks Press: Melbourne)

Beard JB (1973) 'Turfgrass: science and culture.' (Prentice-Hall, Inc.: Englewood Cliffs, NJ)

Bowman DC, Cherney CT, Rufty TW (2002) Fate and transport of nitrogen applied to six warm-season turfgrasses. Crop Science $\mathbf{4 2}$, 833-841.

Brink GE, Rowe DE, Sistani KR, Adeli A (2003) Bermudagrass cultivar response to swine effluent application. Agronomy Journal 95, 597-601.

Broomhall P, Menzel CM (2002) Irrigation strategies for warm-season turfgrasses. Turf Craft International 87, 35-38.

Brown ME (1939) Some effects of temperature on the growth and chemical composition of certain pasture grasses. Missouri Agricultural Experimental Station Research Bulletin 299, 1-76.

Burton GW, Gates RN, Gascho GJ (1997) Response of Pensacola bahiagrass to rates of nitrogen, phosphorus and potassium fertilizers. Proceedings of the Florida Soil and Crop Science Society 56, 31-35.

Carrow RN, Waddington DV, Rieke PE (2001) 'Turfgrass soil fertility and chemical problems. Assessment and management.' (Ann Arbor Press: Chelsea, MI)

Cisar JL, Snyder GH, Swanson GS (1992) Nitrogen, phosphorus, and potassium fertilization for Histosol-grown St. Augustine grass sod. Agronomy Journal 84, 475-479.

Costanzo SD, O'Donohue MJ, Dennison WC (2003) Assessing the seasonal influence of sewage and agricultural nutrient inputs in a subtropical river estuary. Estuaries 26, 857-865.

Goatley JM, Maddox V, Lang DJ, Crouse KK (1994) 'Tifgreen' bermudagrass response to late-season application of nitrogen and potassium. Agronomy Journal 86, 7-10.

Harris GP (2001) Biogeochemistry of nitrogen and phosphorus in Australian catchments, rivers and estuaries: effects of land use and flow regulation and comparisons with global patterns. Marine and Freshwater Research 52, 139-149. doi:10.1071/MF00031

Jones JR (1980) Turf analysis. Golf Course Management 48(1), 29-32.

Keisling TC (1980) Bermudagrass rhizome initiation and longevity under differing potassium nutritional levels. Communications in Soil Science and Plant Analysis 11, 629-635.

Lovvorn RL (1945) The effect of defoliation, soil fertility, temperature, and length of day on the growth of some perennial grasses. Journal of the American Society of Agronomy 37, 570-582.

Lunt OR (1954) Relation of soils and fertilizer to wear resistance of turfgrass. In 'Proceedings of the Northern California turfgrass conference'. pp. 1-2. 
McCaslin BD, Hughes MR, Baltensperger AA (1989) Nitrogen fertilization $\times$ genotype interactions influence bermudagrass turf quality characteristics. Journal of the American Society for Horticultural Science 114, 65-68.

McCrimmon JN (1998) Effect of nitrogen and potassium on the macronutrient content of fifteen bermudagrass cultivars. Communications in Soil Science and Plant Analysis 29, 1851-1861.

McCrimmon JN (2002) Macronutrient and micronutrient concentrations of seeded bermudagrasses. Communications in Soil Science and Plant Analysis 33, 2739-2758. doi:10.1081/CSS120014477

Picchioni GA, Quiroga-Garza HM (1999) Growth and nitrogen partitioning, recovery, and losses in bermudagrass receiving soluble sources of labelled ${ }^{15}$ nitrogen. Journal of the American Society for Horticultural Science 124, 719-725.

Pritchett WL, Horn GC (1966) Fertilization fights turf disorders. Better Crops and Plant Food 50(3), 22-25.

Short D, Colmer T (1999) An evaluation of the water requirements for a diverse range of turf species under WA conditions. Australian Parks and Leisure 2(1), 8-12.

Shuman LM (2004) Runoff of nitrate nitrogen and phosphorus from turfgrass after watering-in. Communications in Soil Science and Plant Analysis 35, 9-24. doi:10.1081/CSS-120027631

Taylor SL, Roberts SC, Walsh CJ, Hatt BE (2004) Catchment urbanisation and increased benthic algal biomass in streams: linking mechanisms to management. Freshwater Biology 49, 835-851. doi:10.1111/j.1365-2427.2004.01225.x

Trenholm LE, Dudeck AE, Sartain JB, Cisar JL (1998) Bermudagrass growth, total non-structural carbohydrate concentration, and quality as influenced by nitrogen and potassium. Crop Science 38, $168-174$.
Turner TR, Hummel NW (1992) Nutritional requirements and fertilization. In 'Turfgrass agronomy. Monograph number 32'. (Eds DV Waddington, RN Carrow, RC Shearman) pp. 385-439. (American Society of Agronomy: Madison, WI)

Unruh JB, Gaussoin RE, Wiest SC (1996) Basal growth temperatures and growth rate constants of warm-season turfgrass species. Crop Science 36, 997-999.

Wong JWC, Chan CWY, Cheung KC (1998) Nitrogen and phosphorus leaching from fertilizer applied on golf course: lysimeter study. Water, Air and Soil Quality 107, 335-345. doi:10.1023/ A: 1005096122921

Woodard KR, French EC, Sweat LA, Graetz DA, Sollenberger LE, et al. (2003) Nitrogen removal and nitrate leaching for two perennial, sodbased forage systems receiving dairy effluent. Journal of Environmental Quality 32, 996-1007.

Youngner VB (1959) Growth of U-3 bermudagrass under various day and night temperatures and light intensities. Agronomy Journal 51, $557-559$.

Youngner VB (1960) Temperature, light and growth of turfgrass. In 'Proceedings of the 31st annual Golf Course Superintendents' Association of America conference'. pp. 37-39.

Youngner VB (1961) Growth and flowering of Zoysia species in response to temperature, photoperiod and light intensities. Crop Science 1, 91-93.

Received 18 November 2004, accepted 2 December 2005

Appendix 1. Description of the grasses used in the experiment (Aldous and Chivers 2002)

Cynodon dactylon and C. dactylon $\times$ C. transvaalensis hybrids are referred to as bermudagrass and hybrid bermudagrass, respectively. $C$. transvaalensis originated in southern Africa, whereas $C$. dactylon is found worldwide. They are the most widely used warm-season grasses in southern USA with many cultivars, some with Australian germplasm. They are popular in Australia, with many cultivars sold under licence. They are slow to come away in spring in the cool subtropics, and so need careful management, but are hard wearing and have some salt tolerance. Most lines have poor shade tolerance, and many require regular maintenance to keep out weeds and other grasses. Some cultivars thatch heavily if overfertilised and mown infrequently. 'Winter Green' and the hybrid 'Tifgreen' ('Bermuda 328') are used here.

Digitaria didactyla (Queensland blue couch) is native to southern Africa, and is naturalised in northern Australia. It is a popular warm-season turf, especially for home gardens in coastal Queensland, and performs better than bermudagrass on sands. It has soft leaves and moderate wearability compared with bermudagrass, but thins out under shade. Some commercial lines in Australia are of mixed quality. An unimproved line used here.

Axonopus compressus (broad-leaf carpetgrass) is native to Central and South America and grows well in shaded, wet areas. It is common in northern Australia and is often weedy. It is the preferred turfgrass species in coastal north Queensland and Darwin, although it thins out if mowed low.

Paspalum notatum (bahiagrass) is native to South America, and naturalised in Australia. It is a coarse, hard-wearing turf, often found in parks and roadsides, but often regarded as a weed (especially 'Pensacola'). The cultivar used was the line ' 38824 '.

Stenotaphrum secundatum (buffalograss) comes from Central and South Africa, and is widely used in southern USA, especially in Florida where it is known as St Augustine grass. It is used for shaded areas in Australia, with some lines sold under licence. It is less cold tolerant than bermudagrass, but withstands moderate wear and salinity. Many cultivars are sensitive to hormone herbicides used to control broadleaf weeds. The cultivar used was 'Palmetto'.

Eremochloa ophiuroides (centipedegrass) is native to China and has adapted to the soils and climates of southern USA. It grows well on poor soils, and requires less maintenance than bermudagrass. It is more cold tolerant than buffalograss, but less tolerant than bermudagrass. Several cultivars are sold in the USA, but are only available from specialists in Australia. 'Centec' was used in this experiment.

Zoysia japonica (zoysiagrass, Japanese lawngrass) is indigenous to Asia and the northern Pacific, and is widely used in Japan, Korea, China and southern USA. It is attractive in summer; however, winter dormancy and browning detract from its value in cool areas. Vegetative types superior to seedling material are becoming available in Australia. The cultivar used was 'ZT-11'. 